\title{
HAWTHORN (CRATAEGUS L.) TAXA AND THEIR HYBRIDS IN NORTH-WESTERN ROMANIA: A RECOMMENDATION FOR NATIONAL IDENTIFICATION KEYS BASED ON MORPHOMETRIC ANALYSES
}

\author{
Thomas KUHN, Boróka JANCSÓ, Eszter RUPRECHT \\ Babeş-Bolyai University, Faculty of Biology and Geology, Department of Biology, 42 Republicii str., \\ RO-400015 Cluj-Napoca, Romania \\ e-mail: kuhnthomas89@yahoo.com
}

\begin{abstract}
Crataegus species are common and widespread shrubs or small trees across Europe, and are of considerable ecological and agricultural importance. However, controversy still surrounds the taxonomy and ecology of this genus, mainly due to frequent hybridization between sympatric species and introgression of genes. Considering the poor representation of Crataegus-related research in the Romanian botanical literature, we investigated the occurrence and morphology of native Crataegus species and their putative hybrids in north-western Romania. We collected herbarium specimens from three regions (Zărandului Mountains, Transylvanian Plain, Călata region), from a variety of habitats, including forests, grasslands and forest-grassland ecotones. Morphometric measurements were taken on a total of 34 fruit-, leaf- and stipule characters on generative shoots. We used PCA and Random Forest analysis to select for the 'best' characters differentiating between species and hybrids. We identified ten different Crataegus taxa, including species, subspecies, varieties and their hybrid nothotaxa: Crataegus monogyna (mainly in grasslands), C. rhipidophylla var. rhipidophylla, C. rhipidophylla var. lindmannii and C. laevigata subsp. laevigata, C. laevigata subsp. palmstruchii (mainly in forests), C. $\times$ kyrtostyla nothovar. domicensis, C. $\times$ media, C. $\times$ macrocarpa nothovar. macrocarpa and $C . \times$ macrocarpa nothovar. hadensis (mainly in forest openings and near forest edges). The most common taxa identified was $C . \times$ kyrtostyla nothovar. kyrtostyla (common in grasslands, rarer in forests). The best differentiating characters between species and hybrids were number of styles, fruit length, number of teeth on stipules, position of sepals on mature fruits, number of serrations on basal leaf lobe, ratio between serrate part of lower leaf lobe and the entire part, depth of basal sinus, and ratio between sepal length and width. Based on the results of the morphometric analysis and literature review, we constructed national identification keys of all Crataegus taxa identified in this study and other confirmed taxa present in Romania. Additionally, we have illustrated the most common six identified taxa (including hybrids).
\end{abstract}

Keywords: Călata region, Crataegus laevigata, Crataegus monogyna, Crataegus rhipidophylla, Crataegus $\times$ kyrtostyla, Crataegus $\times$ macrocarpa, Crataegus $\times$ media, identification keys, hybridization, morphometry, Transylvania, Transylvanian Plain, Zărandului Mountains.

\section{Introduction}

The genus Crataegus L. (Rosaceae) includes several hundred species of shrubs and small trees native to temperate and subtropical regions of the Northern Hemisphere. Although most species are widespread and relatively common, confusion and controversy still surround numerous aspects of their taxonomy and ecology, often referred to in the botanical literature as the "Crataegus problem" [26, 10]. The main reason for this is frequent hybridization, usually between sympatric species, followed by introgression. Hybridization and introgression causes great morphological 
variability and the appearance of intermediate morphological characters within populations, blurring taxa boundaries, thus significantly complicating taxa identification $[6,7]$. The taxonomy is further complicated by the fact that numerous taxa described as species are in fact apomictic microspecies of presumably hybrid origin [7, 19]. Furthermore, only older (generative) individuals can be identified with confidence, and differentiation between hybrids and species sometimes requires multiple organs and structures from different phenological stages [6, 19].

Since the 1970s, numerous studies have been published examining hybridization and introgression in European Crataegus populations based on statistical analysis of morphometric measurements $[1,3,4,5,14,6,10,30,31]$. These techniques proved to be a successful tool in the identification of hybrids and the quantification of introgression, and were crucial in the understanding of morphological variability of Crataegus populations across different landscapes and regions [3, 4, 14, 24]. However, landscape structure and land-use history can influence regional hybridization frequency and introgression patterns in populations, which can result in unique morphologies within certain regions. Furthermore, studies use different combinations of morphometric parameters for the identification of Crataegus taxa, which can lead to slightly varying classification of the same specimens. In these studies, sample sizes are often very small and the specimens collected sometimes lack vital structures for certain identification.

In Romania, so far, no attempt has been made to study the morphology and taxonomy of Crataegus taxa in detail. The first comprehensive floristic surveys, including records and descriptions of Crataegus species from the current territory of Romania, are from the early and mid-19th century. Fuss [13] mentions four taxa: Crataegus oxyacantha L, C. intermedia Fuss (et Schur?) (probably heterotypic synonym of C. monogyna Jacq.), C. monogyna Jacq., and C. nigra W. et K. Kanitz [17] enumerates three of these taxa except $C$. intermedia Fuss (et Schur?). Janka [15] mentions C. rosaeformis Janka (syn. of C. rhipidophylla var. rhipidophylla Gand.) for the first time from the "Banat" region and provides also a short description of this taxa. However, this species is almost completely ignored or synonymized in later botanical literature until the second half of the 20th century. In the early 20th century, Cserey [9] and Jávorka [16] enumerate $C$. pentagyna W. et K., C. monogyna Jacq., C. oxyacantha L. and C. nigra W. et K. Later, Nyárádi [23] identifies two Crataegus species from Transylvania (more exactly from the surroundings of Cluj-Napoca), C. oxyacantha L. and C. monogyna Jacq. In the 1950s, the fourth volume of the Romanian Flora [29] described four species: C. nigra Waldst. \& Kit., C. pentagyna Willd., C. oxyacantha L. (synonym of C. laevigata (Poir.) DC.), and C. monogyna Jacq., respectively numerous microspecies. Here, $C$. rhipidophylla is still considered a subspecies of $C$. monogyna (C. monogyna subsp. calycina (Peterm.) Cajander). Later, Dihoru and Dihoru [11] compared the morphology of Crataegus monogyna and C. curvisepala Lindm. (syn. C. rhipidophylla Gand.) based on field observations and European literature [1,3], recognising C. curvisepala as a distinct species. Ciocârlan [8] accounted for five species in Romania, with C. rhipidophylla Gand. treated as a distinct species. He also differentiated between two varieties of C. rhipidophylla: var. rhipidophylla Gand. and var. lindmannii (Hrabětová) K.I. Christensen. For C. monogyna, three microspecies are mentioned by him: subsp. azarella (Griseb.) Franco, subsp. monogyna Jacq. and subsp. brevispina (Kunze) Franco. C. laevigata (syn. of C. oxyacantha in Flora RPR [29]) has no infraspecific classification here. Oprea [25] enumerated ten species and microspecies and three nothospecies from Romania and also enumerated illegitimate names and synonyms: he differentiated between two subspecies of C. laevigata, subsp. palmstruchii (Lindm.) Franco and 
subsp. laevigata (Poir.) DC., mentioned a fourth subspecies of C. monogyna, subsp. lasiocarpa (Lange) K.I. Christensen, and treated C. calycina Peterm. (with two subspecies) as a distinct taxa (despite the fact that $C$. calycina ssp. calycina Peterm. is currently considered synonymous with the nothospecies C. x macrocarpa Hegetschw. respectively C. calycina ssp. curvisepala (Lindm.) Franco is synonimous with $C$. rhipidophylla var. lindmannii $[7,12]$. In addition, three nothospecies are mentioned by Oprea [25]: C. $\times$ kyrtostyla Pojark. (C. monogyna $\times$ C. rhipidophylla), C. $\times$ media Bechst. $(C$. monogyna $\times C$. laevigata $), C . \times$ rubrinervis Lange $(C$. pentagyna $\times C$. monogyna). However, he considered $C . \times$ kyrtostyla as a synonym, probably of $C$. monogyna. Baranec and Kerényi-Nagy [19] mentioned the nothospecies $C . \times$ macrocarpa Hegetschw. (C. rhipidophylla $\times C$. laevigata), which is a common taxon through Central Europe, from Transylvania. In the most recent edition of the Romanian Flora [28], Crataegus taxa are treated similarly as in Ciocârlan [8], again without including hybrids (or nothospecies) into the identification keys. In a more recent study, Kerényi-Nagy et al. [20] enumerated 38 taxa (species, subspecies, varieties, forms, nothospecies, nothosubspecies and nothovarieties) of Crataegus from Sălaj county, Romania. In some aspects, we agree with the opinion of Kerényi-Nagy et al. [19, 20] on the taxonomic and nomenclatural problems regarding Crataegus taxa. However, the existence of many of the enumerated taxa (especially microspecies) is not confirmed either by genetic or by morphometric analyses. Thus, for our study, we have chosen to follow simpler but more widely accepted systematics and nomenclature of the Europaean Crataegus taxa [7,12].

Considering the poor representation of Crataegus-related research in the Romanian botanical literature and the incompleteness of national identification keys, species descriptions and illustrations, our study had the following objectives:

(a). identification of Crataegus taxa and their hybrids in north-western Romania;

(b). finding and ranking of those morphological characters, which are optimal for differentiating between Crataegus taxa and hybrids on a regional scale (mostly Transylvania);

(c). proposing identification-keys for use on a national level, based on the results of our morphometric investigations.

(d). illustration of Crataegus taxa and their hybrids based on morphometric measurements and herbarium specimens;

\section{Material and Methods}

Sampling design and collection of specimens

Our sampling area comprised the north-western part of Romania and sampling sites were selected based on the proportion of open and forested habitats in the landscape. Our goal was to sample Crataegus taxa occurring in both forest and grassland habitats, but also to survey hybridization zones in landscapes with high habitat fragmentation, where the occurrence of hybrids is more probable. Three such regions were selected with altitudes varying between 200 and $500 \mathrm{~m}$ : (a) western part of the Zărandului Mountains, dominated by mostly intact (not fragmented) forest habitats; (b) the central part of the Transylvanian Plain, dominated by open habitats (e.g. grasslands with scattered shrubs, abandoned agricultural fields, roadsides, hedges), and (c) the eastern part of the Călata (HU: Kalotaszeg) region, with a mixed mosaic landscape of open habitats and forests. Herbarium specimens were collected from six sites in each region from multiple locations, including forest habitats, open habitats and grassland-forest ecotones (Fig. 1). We sampled mature, flowering or fruiting Crataegus specimens between July and September 2018 
and 2019. We collected three generative shoots from each specimen, with intact leaves, fruits and stipules. Individuals missing stipules on generative shoots or with unripe fruits were resampled in autumn or during the next spring. In addition, we recorded the dominant and characteristic vascular plant species in a radius of $10 \mathrm{~m}$ around the sampling locations to identify the major phytosociological categories (classes, orders, alliances) in order to characterize the plant associations in which the studied Crataegus taxa occurred. We also identified major habitat classes (e.g. alpine grassland, conifer forest) in locations outside our study regions, where no Crataegus taxa was observed in a wider area. In this way, we hoped to obtain a more complete picture about the phytosociological affiliations of the Crataegus taxa studied.

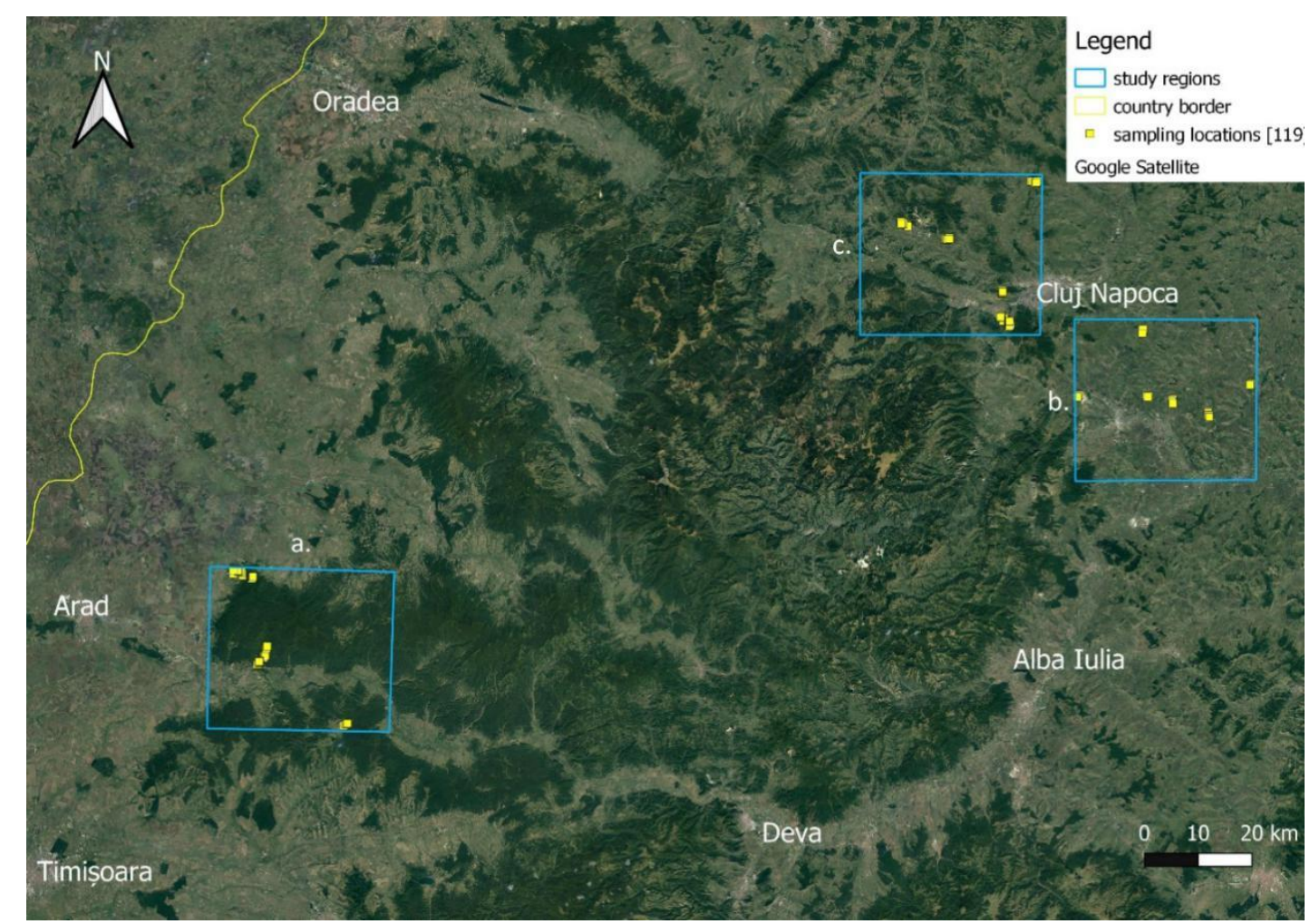

Fig. 1: Sampling regions and locations in the nord-western part of Romania (a. Zărandului Mountains, b. Transylvanian Plain, c. the Călata region; bigger cities are highlighted in white; RO-HU country border is represented by a yellow line).

\section{Taxa identification and morphometric analyses on collected specimens}

Herbarium specimens were digitized on millimetre paper and morphometric measurements were taken in ImageJ software, measuring a total of 34 characters on ripe fruits, stipules and subterminal leaves of the generative shoots. For morphometric analyses, we included most characters considered important in the identification of Central-European Crataegus taxa, prioritizing quantitative characters $[4,5,6,10]$ (Table 1). Identification of specimens was largely based on the identification keys published by Christensen [7], but detailed taxa descriptions and illustrations were also considered $[1,3,4,7,10]$. There is still some confusion surrounding the taxonomic status of C. palmstruchii, and we treated C. palmstruchii as a subspecies of C. laevigata, although some authors suggest it might be an introgressant of hybrid origin $[2,7,19]$. 
Table 1: Morphological characters measured on herbarium specimens (*- "good" characters selected for the PCA - analysis).

\begin{tabular}{|c|c|c|c|}
\hline$\#$ & Variable & Description & $\begin{array}{c}\text { Variable type } \\
\text { (measurement unit) }\end{array}$ \\
\hline \multicolumn{4}{|c|}{$\begin{array}{c}\text { Leaves of flowering shoots } \\
\end{array}$} \\
\hline$* 1$ & $\mathrm{a}$ & length of leaf blade & continuous (mm) \\
\hline 2 & $\mathrm{~b}$ & width of leaf blade & continuous (mm) \\
\hline$* 3$ & b.a & $\mathrm{b} / \mathrm{a}$ & proportional \\
\hline 4 & $\mathrm{c}$ & distance from leaf tip to basal sinus & continuous $(\mathrm{mm})$ \\
\hline$* 5$ & c.a & c / a (location of basal sinus) & proportional \\
\hline 6 & e2 & distance from midrib to basal sinus & continuous (mm) \\
\hline 7 & $\mathrm{f} 2$ & $\begin{array}{l}\text { distance from the tip of basal lobe to } \\
\text { sinus }\end{array}$ & continuous $(\mathrm{mm})$ \\
\hline$* 8$ & f2.e2 & f2 / e2 (depth of basal sinus) & proportional \\
\hline 9 & $\mathrm{~g}$ & length of basal lobe & continuous (mm) \\
\hline 10 & $\mathrm{~h}$ & width of basal lobe & continuous (mm) \\
\hline$* 11$ & h.g & $\mathrm{h} / \mathrm{g}$ ( shape of basal lobe) & proportional \\
\hline 12 & $\mathrm{j} 2$ & length of serrate part of basal lobe & continuous $(\mathrm{mm})$ \\
\hline 13 & $\mathrm{k} 2$ & $\begin{array}{l}\text { length of unserrated part of basal } \\
\text { lobe }\end{array}$ & continuous $(\mathrm{mm})$ \\
\hline$* 14$ & $\mathrm{j} 2 . \mathrm{k} 2$ & $\begin{array}{l}\mathrm{j} 2 / \mathrm{k} 2 \text { (ratio between serrate part of } \\
\text { lobe and the entire part) }\end{array}$ & proportional \\
\hline 15 & i1 & $\begin{array}{l}\text { number of teeth on basal lobe } \\
\text { exterior }\end{array}$ & counted \\
\hline 16 & i2 & $\begin{array}{l}\text { number of teeth on basal lobe } \\
\text { interior }\end{array}$ & counted \\
\hline$* 17$ & $\mathrm{i}$ & $\mathrm{i} 1+\mathrm{i} 2$ (number of teeth on basal lobe) & counted \\
\hline$* 18$ & 1 & length of petiole & continuous (mm) \\
\hline 19 & lob & number of lobes & counted \\
\hline$* 20$ & ang & angle of leaf lobe to midrib & continuous $\left(^{\circ}\right)$ \\
\hline \multicolumn{4}{|c|}{ Stipules of flowering shoots } \\
\hline 21 & stl & length of stipule & continuous (mm) \\
\hline 22 & stw & maximal width of stipule & continuous (mm) \\
\hline 23 & stt1 & number of teeth on convex side & counted \\
\hline 24 & stt2 & number of teeth on concave side & counted \\
\hline$* 25$ & $\mathrm{stt}$ & total number of stipule teeth & counted \\
\hline \multicolumn{4}{|c|}{ Ripe fruits } \\
\hline$* 26$ & frl & length of fruit & continuous (mm) \\
\hline 27 & frw & width of fruit & continuous $(\mathrm{mm})$ \\
\hline 28 & frl.frw & $\mathrm{frl} / \mathrm{frw}$ & proportional \\
\hline 29 & spl & length of sepal & continuous (mm) \\
\hline 30 & spw & width of sepal base & continuous $(\mathrm{mm})$ \\
\hline$* 31$ & spl.spw & spl / spw & proportional \\
\hline$* 32$ & sty & number of styles & counted \\
\hline$* 33$ & spp & position of sepals & $\begin{array}{l}\text { discrete (erect / reflect / } \\
\text { intermediate) }\end{array}$ \\
\hline 34 & spsh & shape of sepal tip & $\begin{array}{l}\text { discrete (acute / obtuse / } \\
\text { intermediate) }\end{array}$ \\
\hline
\end{tabular}

\section{Statistical analysis}

To exclude 'poor' characters with low or no variability between our studied taxa, a series of analyses were performed. Variables representing similar characters or variations of others (e.g. 
length of leaf blade, width of leaf blade, distance from leaf-tip to basal sinus) were grouped and correlated with each other. Furthermore, characters were subjected to one-way ANOVA (normality and homoscedasticy mean) or Kruskal-Wallis test (normality and homoscedasticy violated) followed by post-hoc comparison between taxa. Variation in characters between taxa was also visually inspected and compared on boxplot-diagrams. Finally, highly correlated characters representing similar characters that did not differ significantly between taxa or differed significantly only between two taxa were excluded from later analysis. The resulting data matrix with the selected 'good' morphological characters was further processed. PCA was used for exploring morphological patterns (differences between taxa), because it is a comparatively simple and widely used ordination technique applied in morphometry, furthermore, it has no initial assumptions about the data. Furthermore, to select a subset of the "best" characters for taxa classification that can be included in identification keys, Random Forest (RF) analysis was applied, because it is very resistant to overfitting, and it improves with larger datasets. This machine learning method can generate a set of " $n$ " random decision trees based on the training set with a random subset of " $\mathrm{m}$ " variables (mtry), then cross-validates on the test-set to calculate classification accuracy. The accuracy of the RF classification can be expressed as the OBB-Error rate, which represents the proportion of misclassified observations in the test set. Before running RF, we divided our data intro a training set (75\% of observations) and a test set (25\% of observations) for the purpose of cross-validation. To determine optimal mtry-value, we ran a series of separate RF-models with different mtry-values. The smallest mtry-value was chosen in a way the RF classification accuracy to be maximal. The optimal number of generated trees was set at the value, where the drop in error rate stabilized. Variable importance was interpreted based on Mean Decrease Accuracy (loss of prediction performance after removal of a particular variable from the training data set) and Mean Decrease Gini (the decrease in Gini when a variable is omitted from the training data set) of the predictor variables. Finally, model validation was performed on the test set and classification accuracy was expressed as the proportion between the number of misclassified individuals and all individuals. RF-modelling was applied for two subsets of observations, one including only individuals considered 'pure' species, a second containing all individuals including putative hybrids. All statistical analyses were performed in Rstudio (RStudio Team (2018): Integrated Development for R. RStudio, Inc., Boston, MA URL, http://www.rstudio.com/.) Important packages used were 'FactoMineR' and 'factoextra' for PCA analysis [21, 18] and 'randomForest' for random forest analysis [22].

\section{Construction of proposed identification keys for Romania}

By inspecting the results of PCA analysis and random forest classification, the best, i.e. the highly differentiating, variables were selected. Furthermore, because C. pentagyna, C. nigra, C. $\times$ rubrinervis, $C . \times$ degenii and certain subspecies of C. monogyna (subsp. azarella, subsp. nordica, subsp. brevispina) were not present in our study area but have confirmed occurrence data in Romania [8, 28, 25, 19], we additionally included these taxa in the proposed identification keys based on morphological characters and taxa descriptions from Tutin et al. [32], Chrsitensen [7] and Sârbu et al. [28]. 
Table 2: Frequency, occurrence, and habitat preference of sampled Crataegus taxa. Nr.sp. - number of specimens collected. Under "Phytosociology" the most characteristic phytosociological categories (class, order, aliance) are enumerated, where a taxon can be most likely encountered. Order of phytosociological categories represents relevance in descending order. Nomenclature follows Sanda et al. [27].

\begin{tabular}{|c|c|c|c|}
\hline Taxa & $\begin{array}{l}\text { Nr. } \\
\text { sp. }\end{array}$ & $\begin{array}{l}\text { Occurrence and habitat } \\
\text { preference }\end{array}$ & Phytosociology \\
\hline $\begin{array}{l}\text { C. laevigata subsp. } \\
\text { laevigata }\end{array}$ & 30 & $\begin{array}{l}\text { Common in oak forests, forest } \\
\text { openings and woodlands dominated } \\
\text { by Quercus cerris, } Q \text {. petraea, } Q \text {. } \\
\text { frainetto, or in forest edges in the } \\
\text { Zărandului Mts., sporadic in } \\
\text { Transylvania }\end{array}$ & $\begin{array}{l}\text { Quercetea pubescenti-petraea (Oberdorfer } \\
\text { 1948) Jakucs 1960, Quercetalia roboris R. } \\
\text { Tüxen 1931, Galio schultesii-Carpinenion } \\
\text { Täuber 1992, Lathyro hallersteinii- } \\
\text { Carpinenion Boşcaiu et al. } 1982\end{array}$ \\
\hline $\begin{array}{l}\text { C. laevigata subsp. } \\
\text { palmstruchii }\end{array}$ & 1 & $\begin{array}{l}\text { Very rare near Tăuți (Cluj county, } \\
\text { Transylvania) }\end{array}$ & $\begin{array}{l}\text { Quercetea pubescenti-petraea (Oberdorfer } \\
\text { 1948) Jakucs 1960, Quercetalia roboris R. } \\
\text { Tüxen 1931, Galio schultesii-Carpinenion } \\
\text { Täuber 1992, Lathyro hallersteinii- } \\
\text { Carpinenion Boşcaiu et al. } 1982\end{array}$ \\
\hline C. monogyna & 35 & $\begin{array}{l}\text { Common throughout the studied } \\
\text { regions (north-western part of } \\
\text { Romania), in dry and mesophilous } \\
\text { grasslands, rarer in woodlands }\end{array}$ & $\begin{array}{l}\text { Rhamno-Prunetea } \text { Rivas Goday et Borja } \\
\text { Carbonell 1961, Festuco-Brometea Br.-Bl. } \\
\text { et R. Tüxen in Br.-B1. 1949, } \\
\text { Arrhenatheretalia } \text { R. Tüxen } 1931\end{array}$ \\
\hline $\begin{array}{l}\text { C. rhipidophylla subsp. } \\
\text { lindmannii }\end{array}$ & 29 & $\begin{array}{l}\text { Common in oak forests, forest } \\
\text { openings and woodlands dominated } \\
\text { by Quercus petraea and Carpinus } \\
\text { betulus, or forest edges in } \\
\text { Transylvania and Zărandului Mts. }\end{array}$ & $\begin{array}{l}\text { Quercetea pubescenti-petraea (Oberdorfer } \\
\text { 1948) Jakucs 1960, Quercetalia roboris R. } \\
\text { Tüxen 1931, Galio schultesii-Carpinenion } \\
\text { Täuber 1992, Lathyro hallersteinii- } \\
\text { Carpinenion Boşcaiu et al. } 1982\end{array}$ \\
\hline $\begin{array}{l}\text { C. rhipidophylla subsp. } \\
\text { rhipidophylla }\end{array}$ & 59 & $\begin{array}{l}\text { Common in oak forests, forest } \\
\text { openings and woodlands dominated } \\
\text { by Quercus petraea and Carpinus } \\
\text { betulus, or in forest edges in } \\
\text { Transylvania and Zărandului Mts. }\end{array}$ & $\begin{array}{l}\text { Quercetea pubescenti-petraea (Oberdorfer } \\
\text { 1948) Jakucs 1960, Quercetalia roboris R. } \\
\text { Tüxen 1931, Galio schultesii-Carpinenion } \\
\text { Täuber 1992, Lathyro hallersteinii- } \\
\text { Carpinenion Boşcaiu et al. } 1982\end{array}$ \\
\hline $\begin{array}{l}\text { C. } \times \text { kyrtostyla } \\
\text { nothovar. domicensis }\end{array}$ & 2 & $\begin{array}{l}\text { Sporadic in grasslands and in forest } \\
\text { edges in Transylvania }\end{array}$ & $\begin{array}{l}\text { Rhamno-Prunetea } \text { Rivas Goday et Borja } \\
\text { Carbonell 1961, Festuco-Brometea } \text { Br.-B1. } \\
\text { et R. Tüxen in Br.-B1. 1949, } \\
\text { Arrhenatheretalia } \text { R. Tüxen 1931, } \\
\text { Quercetea pubescenti-petraea (Oberdorfer } \\
\text { 1948) Jakucs }\end{array}$ \\
\hline $\begin{array}{l}\text { C. } \times \text { kyrtostyla } \\
\text { nothovar. kyrtostyla }\end{array}$ & 183 & $\begin{array}{l}\text { Common in grasslands, sometimes } \\
\text { in oak forests, forest openings and } \\
\text { woodlands in Transylvania }\end{array}$ & $\begin{array}{l}\text { Rhamno-Prunetea } \text { Rivas Goday et Borja } \\
\text { Carbonell 1961, Festuco-Brometea Br.-B1. } \\
\text { et R. Tüxen in Br.-B1. 1949, } \\
\text { Arrhenatheretalia } \text { R. Tüxen 1931, } \\
\text { Quercetea pubescenti-petraea (Oberdorfer } \\
\text { 1948) Jakucs }\end{array}$ \\
\hline $\begin{array}{l}\text { C. } \times \text { macrocarpa } \\
\text { nothovar. hadensis }\end{array}$ & 6 & $\begin{array}{l}\text { Sporadic in oak forests, forest } \\
\text { openings and woodlands, or in } \\
\text { forest-edges in Transylvania }\end{array}$ & $\begin{array}{l}\text { Quercetea pubescenti-petraea (Oberdorfer } \\
\text { 1948) Jakucs 1960, Quercetalia roboris R. } \\
\text { Tüxen 1931, Galio schultesii-Carpinenion } \\
\text { Täuber 1992, Lathyro hallersteinii- } \\
\text { Carpinenion Boşcaiu et al. } 1982\end{array}$ \\
\hline $\begin{array}{l}\text { C. } \times \text { macrocarpa } \\
\text { nothovar. macrocarpa }\end{array}$ & 9 & $\begin{array}{l}\text { Sporadic in oak forests, forest } \\
\text { openings and woodlands, or in } \\
\text { forest-edges in Transylvania }\end{array}$ & $\begin{array}{l}\text { Quercetea pubescenti-petraea (Oberdorfer } \\
\text { 1948) Jakucs 1960, Quercetalia roboris R. } \\
\text { Tüxen 1931, Galio schultesii-Carpinenion } \\
\text { Täuber 1992, Lathyro hallersteinii- } \\
\text { Carpinenion Boşcaiu et al. } 1982\end{array}$ \\
\hline C. $\times$ media & 14 & $\begin{array}{l}\text { Sporadic in forest-edges, } \\
\text { woodlands, forest openings and } \\
\text { grasslands in Transylvania }\end{array}$ & $\begin{array}{l}\text { Rhamno-Prunetea } \text { Rivas Goday et Borja } \\
\text { Carbonell 1961, Festuco-Brometea Br.-Bl. } \\
\text { et R. Tüxen in Br.-B1. 1949, } \\
\text { Arrhenatheretalia } \text { R. Tüxen } 1931\end{array}$ \\
\hline Total & 368 & & \\
\hline
\end{tabular}




\section{Results}

\section{Identified Crataegus taxa from the study regions}

We identified ten different Crataegus taxa, including species, subspecies, varieties and their hybrid nothotaxa (Table 2). C. monogyna Jacq. was common in many types of grasslands and other open habitats. C. rhipidophylla var. rhipidophylla Gand., C. rhipidophylla var. lindmannii (Hrab.-Uhr.) Christensen and C. laevigata subsp. laevigata (Poir.) DC. were common in broadleaved oak forests, forest openings or woodlands, but sporadically occurred in grasslands near forests (Table 2). While C. laevigata was slightly more specialist and occurred mainly in oak forests dominated by Quercus cerris, $Q$. petraea and $Q$. frainetto, C. rhipidophylla was more generalist in its habitat preference and was frequent in many types of oak forests or oak-hornbeam forests (Table 2). C. laevigata subsp. palmstruchii (Lind.) Franco was much rarer and was observed mainly in forest edges. The most common nothotaxon was $C . \times$ kyrtostyla nothovar. kyrtostyla Fingerhuth (C. rhipidophylla var. rhipidophylla $\times$ C.monogyna), which represented also the most common Crataegus taxon observed if including introgressants, which were common in open habitats and sporadic in forests (Table 2). Relatively rare hybrids were $C . \times$ kyrtostyla nothovar. domicensis (Hrabetova'-Uhrova) Christensen $(C$. rhipidophylla var. lindmannii $\times C$. monogyna), $C . \times$ media Bechst. $(C$. laevigata ssp. laevigata $\times C$. monogyna), $C . \times$ macrocarpa nothovar. macrocarpa Hegetschw. (C. rhipidophylla var. rhipidophylla $\times$ C. laevigata ssp. laevigata) and $C$. $\times$ macrocarpa nothovar. hadensis (Hrabetova-Uhrova) Christensen ( $C$. rhipidophylla var. rhipidophylla $\times$ C. laevigata subsp. palmstruchii), all predominantly occurring in forest openings, forest-edges, woodlands or grasslands near forests (Table 2). None of the enumerated Crataegus taxa was observed (if so, then extremely rarely) in marshes, bogs, saltsteppes, subalpine or alpine grasslands, nor in beech or spruce forests.

\section{Ordination results}

Following variable selection with univariate statistics, 14 variables (Table 1) were included in the PCA-analysis. The first principal component accounted for $33.3 \%$, the second for $25.6 \%$ of the total variance (with $58.9 \%$ of the total variance explained). The species $C$. monogyna, $C$. rhipidophylla and $C$. laevigata specimens differentiated well on the first and also on the second PCA-axis (Figure 2 a). Hybrid specimens partially overlapped with their parent taxa. In the case of $C . \times$ kyrtostyla, most specimens agglomerated around $C$. monogyna and only a few overlapped with $C$. rhipidophylla. As is the case for $C$. $\times$ media, with specimens more proximal to $C$. monogyna and comparatively distant from $C$. laevigata. Furthermore, specimens of $C . \times$ macrocarpa nothovar. macrocarpa overlapped partially with $C$. laevigata, and most of them were comparatively distant from $C$. rhipidophylla var. rhipidophylla individuals, while $C . \times$ macrocarpa nothovar. hadensis specimens were positioned close to C. rhipidophylla var. rhipidophylla (Figure 2 a). C. laevigata differentiated on the second PCA axis from C. monogyna and $C$. rhipidophylla, based on the "number of styles" and the "depth of basal sinus" (Figure $2 \mathrm{~b}$ ). In contrast C. monogyna differentiated from C. rhipidophylla predominantly on the first PCA axis (and to a very small degree on the second axis), based largely on the contribution of the "number of teeth on the basal lobe" and the "total number of stipule teeth" (Figure $2 \mathrm{~b}$ ).

Random Forest classification results

For the data set containing only 'pure' species, after RF-modelling on training data, optimal mtry-value (number of randomly chosen characters) was determined at 3 , while optimal number of generated trees at 600 . OOB-error rate was $6.72 \%$ and classification accuracy after model- 
validation on test set was $100 \%$. Based on Mean Decrease Accuracy values and Mean Decrease in Gini values, the best predictor variables for classification were: position of sepals on mature fruits, number of styles, number of teeth on stipules, and number of serrations on basal leaf lobe. For the complete data set containing species and their hybrids, optimal mtry-value was determined at 4 , while optimal number of generated trees at 600 . OOB-error rate was $8.79 \%$ and classification accuracy after model-validation on test set was 96.73\%. Based on Mean Decrease Accuracy values and Mean Decrease in Gini values, the best predictor variables for classification were: number of styles, fruit length, number of teeth on stipules, position of sepals on mature fruits, number of serrations on basal leaf lobe, ratio between serrate part of lower leaf lobe and the entire part, depth of basal sinus, and ratio between sepal length and width.

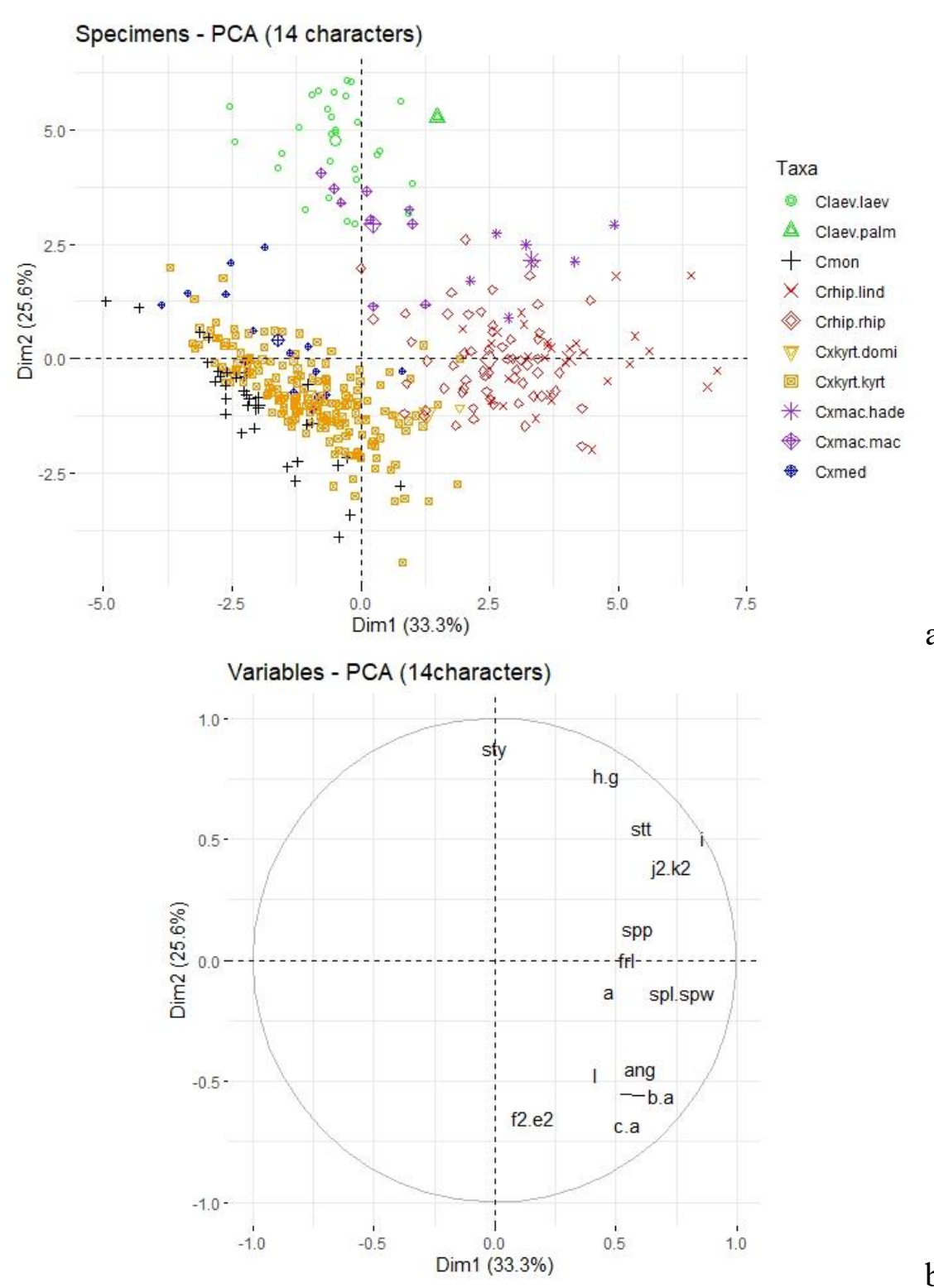

a.

b.

Figure 2: Biplots of PCA analysis based on 14 characters: a. specimen scores; b. variable scores. a. Abbreviation of taxa: Claev.laev - C. laevigata subsp. laevigata, C. laev.palm - C. laevigata subsp. palmstruchii, Cmon - C. monogyna, C.rhip.lind - C. rhipidophylla var. lindmannii, C. rhip.rhip - C. rhipidophylla var. rhipidophylla, C.xkyrt.kyrt - C. $\times$ kyrtostyla nothovar. kyrtostyla, C.xkyrt.domi - C. $\times$ kyrtostyla nothovar. domicensis, Cxmac.mac - C. × macrocarpa nothovar. macrocarpa, Cxmac.hade - C. $\times$ macrocarpa nothovar. hadensis, Cxmed - C. $\times$ media. b. For character abbreviations see Table 1. 


\section{Proposed identification keys of Crataegus taxa for Romania}

Based on the results of PCA and RF-analysis, we included the following predictor variables in our proposed identification keys to differentiate between taxa and major groups: number of styles, fruit length, position of sepals on mature fruits, number of teeth on stipules, number of serrations on basal leaf lobe, ratio of serrate part of lower leaf lobe, depth of basal sinus, and the ratio between sepal length and sepal width. We prioritized fruit characters and included fruit colour and number of styles (or pyrenes if styles are not visible) for the basal split between major groups. Fruits are present on the shrubs throughout the most part of the year, even in the winter months.

For identification, generative (flowering or fruiting) shoots should be collected containing flowers or ripe fruits, leaves and stipules. Optimal collection time is late summer to early autumn. Leaf characters in identification keys are valid only for subterminal leaves of generative shoots. Number of styles is equal to the number of pyrenes (if styles are damaged or not visible, pyrenes should be counted). Text highlighted with grey is compiled on the basis of Tutin et al. [32] and Christensen [7], and describes taxa that were not sampled in the present study. Nomenclature follows Christensen [7] or in the case of taxa missing from this monograph, Euro+Med [12] online database.

\section{Identification keys for species, subspecies, varieties, nothospecies, nothovarieties of Crataegus:}

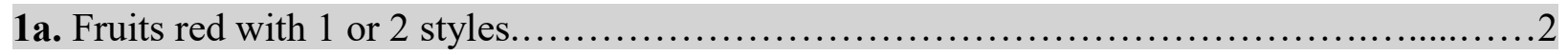

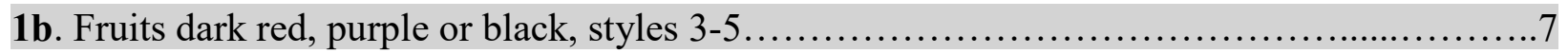

2a. all fruits with 1 style. Basal leaf sinus relatively deep $>1 / 2$ the distance to midrib...............3

2b. fruits with 2 styles or 1 and 2 styled fruits mixed on the same specimen. Lower sinus relatively shallow, $1 / 2-1 / 4$ the distance to midrib............................................ 5

3a. all stipules of generative shoots completely entire. Fruits small and round, 7-11 mm, sepals approximately as long as wide, obtuse, distal part of basal leaf lobe with 0-5 coarse teeth: $\boldsymbol{C}$. monogyna Jacq. (Figure 3 c)

+ . leaves coriaceous, predominantly glabrous, $0.5-1.5 \mathrm{~cm}$ in length, with sclerificated margins and glaucous underside. Small shrubs $<1 \mathrm{~m}$ in height: C. monogyna subsp. brevispina (Kunze) Franco + . leaves not coriaceous or just slightly coriaceous with no sclerificated margins, larger, $2-5 \mathrm{~cm}$ in length................................................................\#

\#. twigs and leaves densely pubescent, hypanthium villous: C. monogyna subsp. azarella (Griseb.) Franco

\#. twigs and leaves predominantly glabrous.

++. hypanthium villous, leaves (3) 5-7 lobed, 3- $5 \mathrm{~cm}$ in length, greyish beneath, petiole 2-2.5 mm: C. monogyna subsp. nordica Franco

++ . hypanthium glabrous, leaves 3-5 lobed, $2.5-3.5 \mathrm{~cm}$ in length, light green beneath, petiole 5-15 $\mathrm{mm}$ : C. monogyna subsp. monogyna Jacq.

3b. all or at least some stipules of generative shoots denticulate. .4

4a. stipules of generative shoots regularly denticulate with 7-25 fine glandular teeth on both margins. Fruits large, ovoid, 10-14 mm in length, sepals much longer than wide, acute, basal leaflobe with 7-25 serrations on most of its length: C. rhipidophylla Gand.

+. Sepals on ripe fruits predominantly erect: C. rhipidophylla var. lindmannii (Hrabětová) K.I. 
Christensen

+. Sepals on ripe fruits predominantly reflexed: C. rhipidophylla var. rhipidophylla Gand. (Figure 3 c)

4b. stipules of generative shoots irregularly denticulate often only on one margin, with 5-18 glandular teeth. Basal leaf-lobe with 2-10 fine or coarse teeth or serrations mainly on the distal part of the lobe: $\boldsymbol{C} . \times$ kyrtostyla Fingerh. (C. monogyna $\times$ C. rhipidoplylla)

+ . Sepals on ripe fruits predominantly erect: $C . \times$ kyrtostyla nothovar. domicensis (Hrabetova'Uhrova) Christensen (C. monogyna $\times$ C. rhipidophylla var. lindmannii)

+ . Sepals on ripe fruits predominantly reflexed: $C . \times$ kyrtostyla nothovar. kyrtostyla Fingerh. $(C$. monogyna $\times$ C. rhipidophylla var. rhipidophylla ) (Figure $3 \mathrm{~d}$ )

5a. all fruits with 2 styles. Fruits small, round, 6-11 mm, sepals approximately as long as wide. Stipules with 14-28 fine glandular teeth. Edge of basal leaf lobe crenate with 7-15 teeth, basal sinus shallow, on average 1/4 the distance to midrib: $\boldsymbol{C}$. laevigata (Poir.) DC.

+. Sepals on ripe fruits predominantly erect: C. laevigata subsp. palmstruchii (Lind.) Franco

+ . Sepals on ripe fruits predominantly reflexed: C. laevigata subsp. laevigata (Poir.) DC. (Figure 3 a)

5b. 2-styled and 1-styled fruits occur on the same specimen.................................6

6a. all stipules of generative shoots regularly denticulate on both margins with 14-22 fine, glandular teeth. Basal sinus relatively shallow, 1/2-1/4 the distance to midrib. Basal leaf lobe with 12-20 fine teeth along most of its length: $\boldsymbol{C}$. $\times$ macrocarpa Hegetschw.

+ . Sepals on ripe fruits predominantly erect: $C . \times$ macrocarpa nothovar. hadensis (HrabetovaUhrova) Christensen (C.rhipidophylla var. rhipidophylla $\times$ C. laevigata ssp. palmstruchii)

+ Sepals on ripe fruits predominantly reflexed: $C . \times$ macrocarpa nothovar. macrocarpa Hegetschw. (C.rhipidophylla var. rhipidophylla $\times$ C. laevigata ssp. laevigata) (Figure $3 \mathrm{f}$ )

6b. all or at least some stipules of generative shoots irregularly denticulate with 1-12 teeth, often with only one margin denticulate, with the other margin entire or subentire: $\boldsymbol{C}$. $\times$ media Bechst. (C. monogyna $\times$ C. laevigata) (Figure $3 \mathrm{e})$

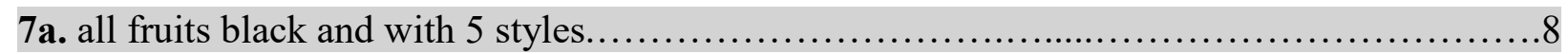

7b. fruits varying in colour from dark red, purple to black, with style number varying between 3-

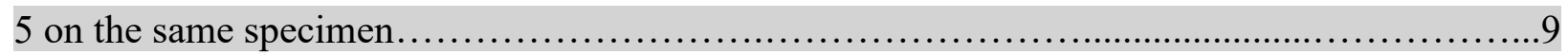

8a. stipules of generative shoots completely entire, twigs and leaves pubescent or glabrous, leaves 3-7 cm in length with vein axils beneath tomentose: C. pentagyna subsp. pentagyna Wild.

8b. stipules of generative shoots densely serrate with $24-47$ teeth, leaves $5-10 \mathrm{~cm}$ in length with 7-11 lobes, twigs and leaves white-greyish densely villous: $\boldsymbol{C}$. nigra Waldst. et. Kit.

9a. all stipules of generative shoots entire, twigs and leaves pubescent or glabrous, leaves 3-7 cm long, glabrous or sometimes with vein axils beneath tomentose: $C \times$ rubrinervis Lange $(C$. pentagyna $\times$ C. monogyna)

9b. stipules of generative shoots more or less irregularly denticulate, twigs and leaves pubescent or glabrous, leaves with 3-21 teeth, 4.2-6.5 cm long with 3-5 lobes: $C$. × degenii Zsák $(C$. nigra $\times$ C.monogyna) 

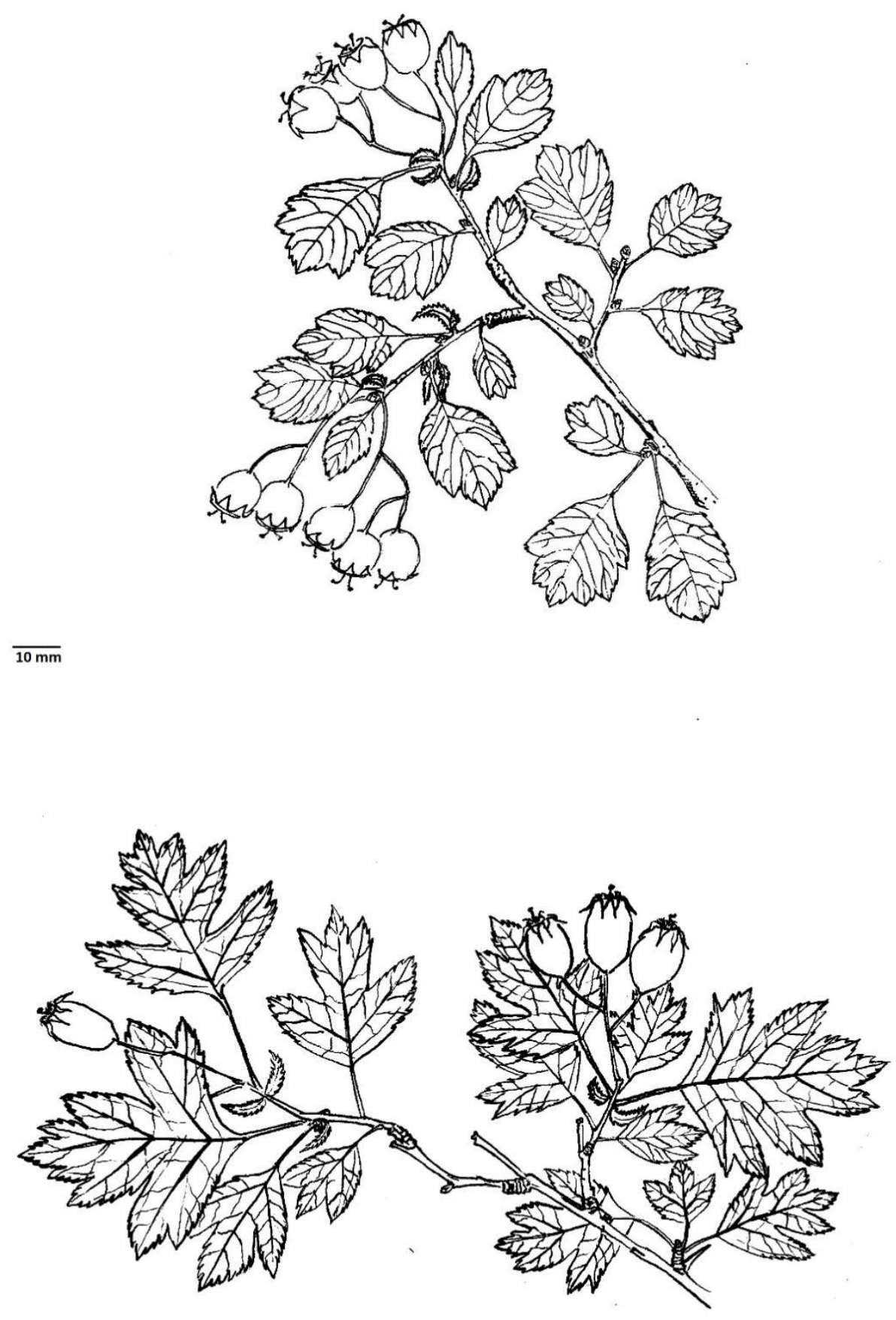

$\overline{10 \mathrm{~mm}}$

b. 

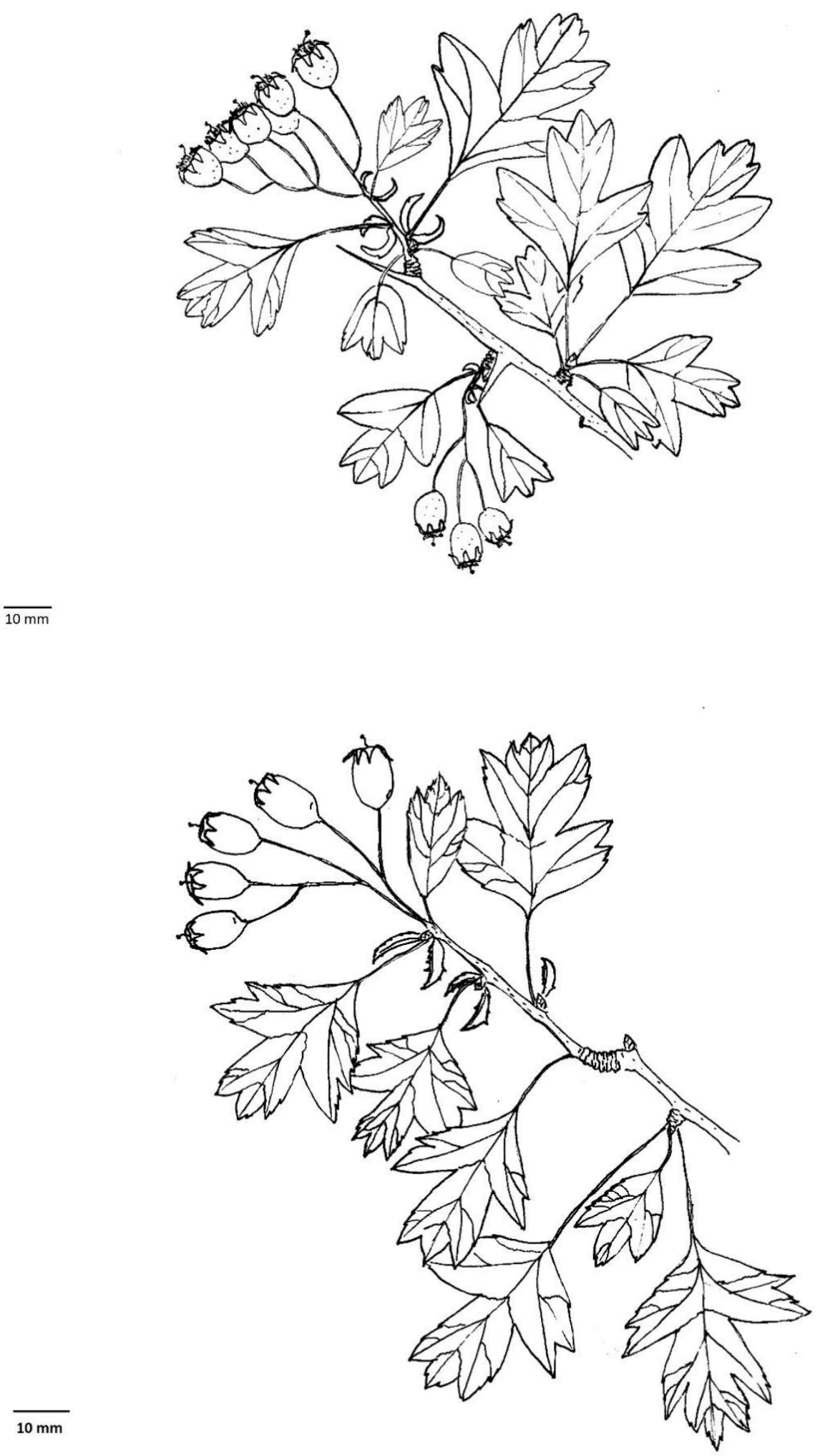

d. 


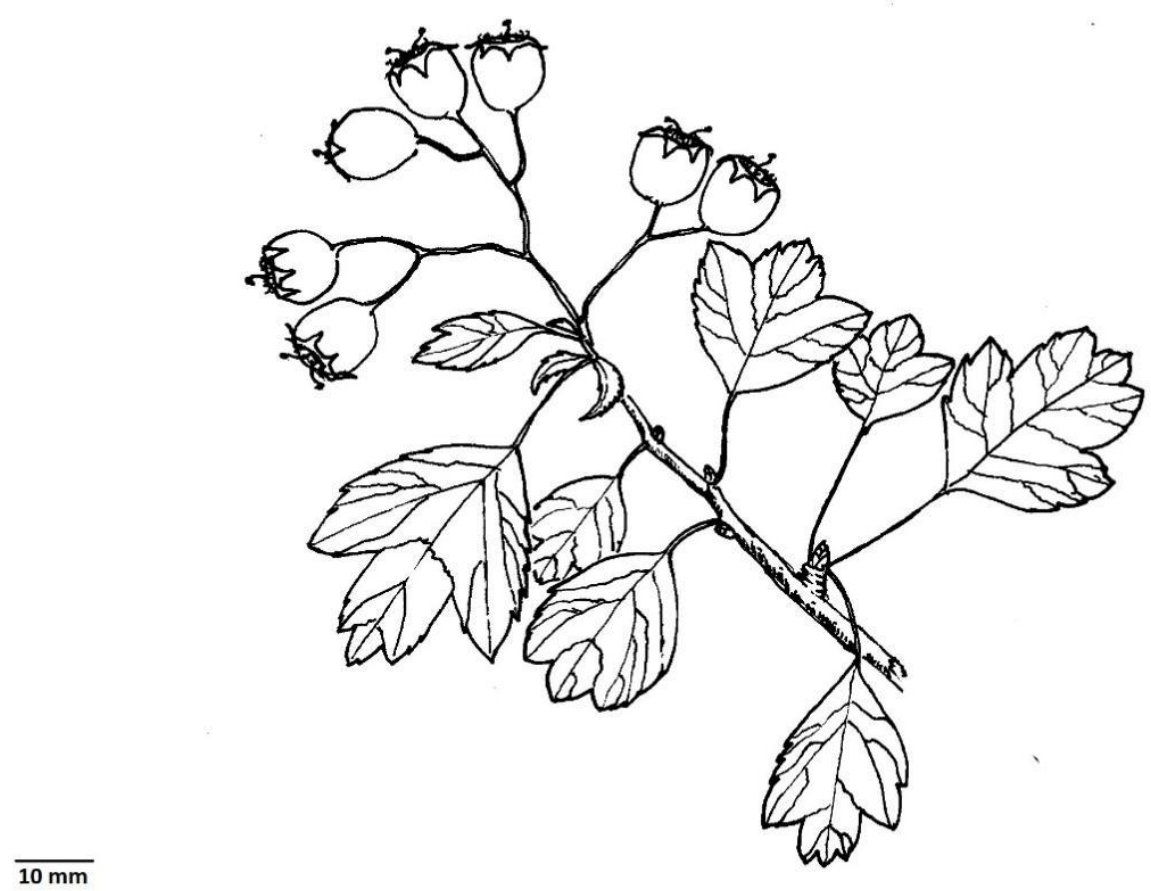

e.

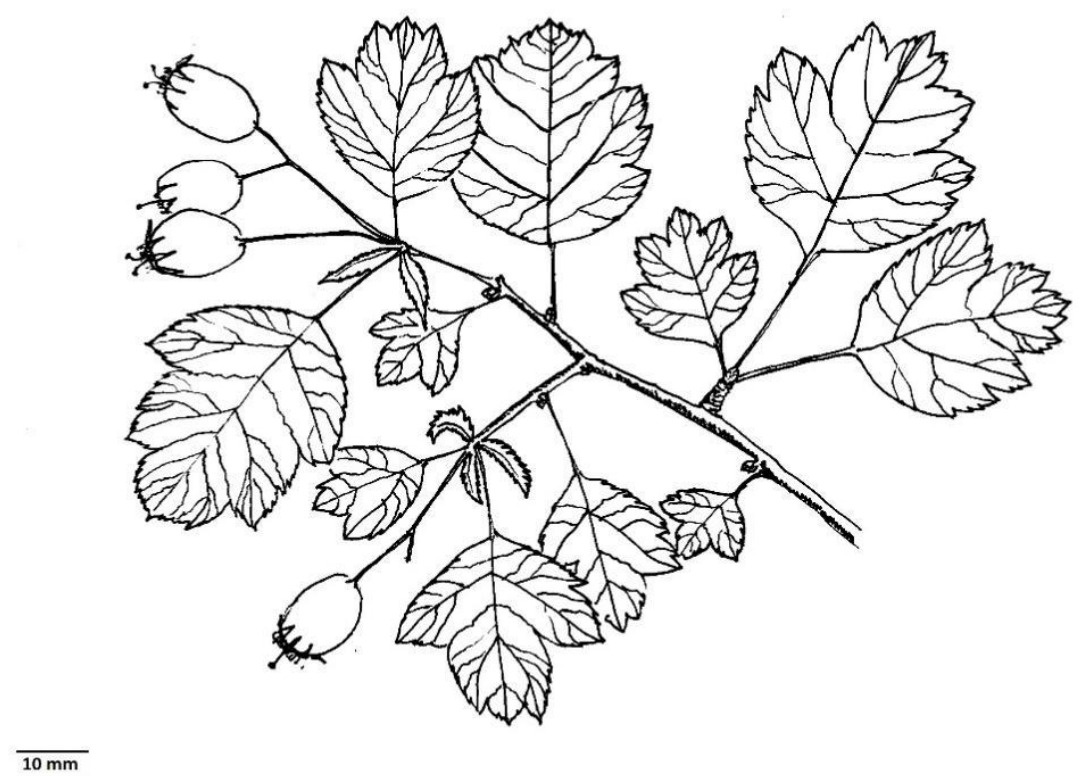

f.

Figure 3: Illustrations of (a) Crataegus laevigata subsp. laevigata, (b) C. rhipidophylla var. rhipidophylla, (c) C. monogyna subsp. monogyna, (d) $C . \times$ kyrtostyla nothovar. kyrtostyla, (e) $C . \times$ media, (f) C. $\times$ macrocarpa nothovar. macrocarpa. 
Table 3: Results of the morphometric measurements of diagnostic characters for the studied Crataegus taxa [ (min) mean \pm se (max) ]. Char - Character, $\mathrm{n}-\mathrm{sample}$ number. For taxa abbreviations see Figure 2. For character abbreviations see Table 1.

\begin{tabular}{|c|c|c|c|c|c|c|c|c|c|c|c|}
\hline \multirow[t]{2}{*}{ \# } & \multirow[t]{2}{*}{ Char. } & \multicolumn{10}{|c|}{ Taxa } \\
\hline & & $\begin{array}{c}\text { Claev.laev } \\
(\mathbf{n}=\mathbf{3 0})\end{array}$ & $\begin{array}{c}\text { Claev.palm } \\
(n=1)\end{array}$ & $\begin{array}{l}\text { Cmon } \\
(n=35)\end{array}$ & $\begin{array}{l}\text { Crhip.lind } \\
(n=29)\end{array}$ & $\begin{array}{c}\text { Crhip.rhip } \\
(n=59)\end{array}$ & $\begin{array}{c}\text { Cxkyrt.domi } \\
(n=2)\end{array}$ & $\begin{array}{c}\text { Cxkyrt.kyrt } \\
(\mathrm{n}=183)\end{array}$ & $\begin{array}{c}\text { Cxmac.hade } \\
(n=6)\end{array}$ & $\begin{array}{c}\text { Cxmac.mac } \\
(n=9)\end{array}$ & $\begin{array}{l}\text { Cxmed } \\
(n=14)\end{array}$ \\
\hline \multicolumn{12}{|c|}{$\begin{array}{l}\text { Leaves of flowering shoots } \\
\end{array}$} \\
\hline 1 & a & $\begin{array}{c}(23.33) 32.89 \pm \\
0.81(41.39)\end{array}$ & 34.34 & $\begin{array}{c}(17.02) 26.1 \pm \\
0.86(36.49)\end{array}$ & $\begin{array}{c}(19.61) 35.2 \pm \\
1.26(46.99)\end{array}$ & $\begin{array}{c}(24.9) 35.66 \pm \\
0.77(48.43)\end{array}$ & $\begin{array}{c}(30.92) 31.91 \\
\pm 0.99 \\
(32.89)\end{array}$ & $\begin{array}{c}(20.85) 32.2 \\
\pm 0.44 \\
(53.54)\end{array}$ & $\begin{array}{c}(23.86) 31.46 \\
\pm 1.86(36.54)\end{array}$ & $\begin{array}{c}(25.39) 35.26 \\
\pm 2.68 \\
(47.96)\end{array}$ & $\begin{array}{l}(23.64) 29.98 \\
\pm 1.32(39.12)\end{array}$ \\
\hline 2 & $\mathbf{b}$ & $\begin{array}{c}(14.85) 24.57 \pm \\
0.76(31.71)\end{array}$ & 24.14 & $\begin{array}{l}(11.74) 23.68 \\
\pm 1.01(36.26)\end{array}$ & $\begin{array}{r}(19.38) 35.16 \\
\pm 1.27(49.59)\end{array}$ & $\begin{array}{c}(20.2) 35.7 \pm \\
0.94(53.07)\end{array}$ & $\begin{array}{c}(29.69) 30.02 \\
\pm 0.33 \\
(30.34)\end{array}$ & $\begin{array}{c}(15.62) \\
29.26 \pm 0.5 \\
(51.5)\end{array}$ & $\begin{array}{c}(22.06) 29.9 \pm \\
1.74(34.02)\end{array}$ & $\begin{array}{c}(18.44) 27.7 \\
\pm 1.96 \\
(34.66)\end{array}$ & $\begin{array}{l}(17.28) 26.94 \\
\pm 1.99(42.22)\end{array}$ \\
\hline 3 & b.a & $\begin{array}{c}(0.62) 0.75 \pm \\
0.01(0.88)\end{array}$ & 0.7 & $\begin{array}{c}(0.56) 0.91 \pm \\
0.02(1.17)\end{array}$ & $\begin{array}{c}(0.64) 0.99 \pm \\
0.02(1.15)\end{array}$ & $\begin{array}{c}(0.69) 1 \pm 0.01 \\
(1.2)\end{array}$ & $\begin{array}{c}(0.93) 0.95 \pm \\
0.02(0.97)\end{array}$ & $\begin{array}{c}(0.56) 0.91 \\
\pm 0.01 \\
(1.33)\end{array}$ & $\begin{array}{l}(0.9) 0.95 \pm \\
0.02(1.04)\end{array}$ & $\begin{array}{c}(0.71) 0.79 \pm \\
0.04(0.98)\end{array}$ & $\begin{array}{c}(0.69) 0.89 \pm \\
0.04(1.13)\end{array}$ \\
\hline 4 & c & $\begin{array}{c}(5.56) 11.65 \pm \\
0.75(20.29)\end{array}$ & 14.79 & $\begin{array}{c}(6.82) 14.41 \pm \\
0.84(26.17)\end{array}$ & $\begin{array}{l}(11.96) 21.89 \\
\pm 0.82(30.26)\end{array}$ & $\begin{array}{l}(12.06) 20.91 \\
\pm 0.56(31.26)\end{array}$ & $\begin{array}{c}(15.97) 16.82 \\
\pm 0.85 \\
(17.67)\end{array}$ & $\begin{array}{l}\text { (7) } 17.28 \pm \\
0.35(31.54)\end{array}$ & $\begin{array}{l}(12.61) 17.15 \\
\pm 1.16(20.97)\end{array}$ & $\begin{array}{c}(10.17) 15.86 \\
\pm 1.26 \\
(21.19)\end{array}$ & $\begin{array}{c}(8.43) 14.49 \pm \\
1.14(20.41)\end{array}$ \\
\hline 5 & c.a & $\begin{array}{c}(0.21) 0.35 \pm \\
0.02(0.59)\end{array}$ & 0.43 & $\begin{array}{c}(0.33) 0.54 \pm \\
0.02(0.74)\end{array}$ & $\begin{array}{c}(0.54) 0.62 \pm \\
0.01(0.71)\end{array}$ & $\begin{array}{c}(0.45) 0.58 \pm \\
0.01(0.72)\end{array}$ & $\begin{array}{c}(0.51) 0.53 \pm \\
0.01(0.54)\end{array}$ & $\begin{array}{c}(0.24) 0.53 \\
\pm 0.01 \\
(0.79)\end{array}$ & $\begin{array}{l}(0.5) 0.54 \pm \\
0.02(0.61)\end{array}$ & $\begin{array}{l}(0.4) 0.45 \pm \\
0.02(0.52)\end{array}$ & $\begin{array}{c}(0.32) 0.48 \pm \\
0.03(0.71)\end{array}$ \\
\hline 6 & e2 & $\begin{array}{l}(4.66) 7.4 \pm \\
0.24(9.92)\end{array}$ & 7.08 & $\begin{array}{c}(2.12) 4.38 \pm \\
0.22(7.15)\end{array}$ & $\begin{array}{c}(2.64) 6.05 \pm \\
0.37(9.3)\end{array}$ & $\begin{array}{c}(3.12) 6.73 \pm \\
0.28(12.66)\end{array}$ & $\begin{array}{c}(4.93) 5.47 \pm \\
0.54(6.01)\end{array}$ & $\begin{array}{c}(1.03) 6.07 \\
\pm 0.12 \\
(13.13)\end{array}$ & $\begin{array}{c}(4.85) 6.97 \pm \\
0.66(8.79)\end{array}$ & $\begin{array}{c}(4.76) 8.08 \pm \\
0.77(11.28)\end{array}$ & $\begin{array}{c}(2.93) 6.15 \pm \\
0.52(10.07)\end{array}$ \\
\hline 7 & $\mathbf{f 2}$ & $\begin{array}{l}(2.66) 5.3 \pm \\
0.34(9.65)\end{array}$ & 5.57 & $\begin{array}{c}(1.55) 8.13 \pm \\
0.54(14.83)\end{array}$ & $\begin{array}{c}(8.13) 12.52 \pm \\
0.43(17.25)\end{array}$ & $\begin{array}{c}(5.56) 12.39 \pm \\
0.37(20.76)\end{array}$ & $\begin{array}{c}(9.04) 9.92 \pm \\
0.88(10.79)\end{array}$ & $\begin{array}{c}(3.71) 10.2 \\
\pm 0.22 \\
(19.97)\end{array}$ & $\begin{array}{c}(7.43) 9.26 \pm \\
0.46(10.52)\end{array}$ & $\begin{array}{c}(3.74) 6.65 \pm \\
0.6(9.07)\end{array}$ & $\begin{array}{c}(2.42) 8.28 \pm \\
0.88(12.82)\end{array}$ \\
\hline 8 & f2.e2 & $\begin{array}{c}(0.33) 0.74 \pm \\
0.05(1.44)\end{array}$ & 0.81 & $\begin{array}{l}(0.34) 2.4 \pm \\
0.32(9.23)\end{array}$ & $\begin{array}{c}(1.25) 2.39 \pm \\
0.17(5.33)\end{array}$ & $\begin{array}{c}(0.89) 2.16 \pm \\
0.12(5.11)\end{array}$ & $\begin{array}{c}(1.56) 1.88 \pm \\
0.32(2.19)\end{array}$ & $\begin{array}{c}0.64) 1.96 \\
\pm 0.08 \\
(11.17) \\
\end{array}$ & $\begin{array}{c}(0.99) 1.43 \pm \\
0.18(2.26)\end{array}$ & $\begin{array}{c}(0.63) 0.87 \pm \\
0.09(1.31)\end{array}$ & $\begin{array}{c}(0.38) 1.53 \pm \\
0.21(3.03)\end{array}$ \\
\hline 9 & $\mathbf{g}$ & $\begin{array}{c}(13.07) 17.71 \pm \\
0.5(24.02)\end{array}$ & 16.83 & $\begin{array}{l}(12.13) 17.59 \\
\pm 0.57(24.77)\end{array}$ & $\begin{array}{r}(14.01) 22.57 \\
\pm 0.83(32.78)\end{array}$ & $\begin{array}{c}(14.29) 23.49 \\
\pm 0.6(32.7)\end{array}$ & $\begin{array}{c}(18.45) 18.91 \\
\pm 0.46 \\
(19.37)\end{array}$ & $\begin{array}{c}(13.08) \\
21.87 \pm 0.32 \\
(36.33)\end{array}$ & $\begin{array}{l}(16.67) 20.58 \\
\pm 0.97(23.49)\end{array}$ & $\begin{array}{c}(13.8) 19.75 \\
\pm 1.22 \\
(23.93)\end{array}$ & $\begin{array}{l}(14.85) 20.52 \\
\pm 1.09(28.6)\end{array}$ \\
\hline
\end{tabular}




\begin{tabular}{|c|c|c|c|c|c|c|c|c|c|c|c|}
\hline 10 & $\mathbf{h}$ & $\begin{array}{c}(4.94) 10.72 \pm \\
0.34(14.23)\end{array}$ & 9.98 & $\begin{array}{c}(3.74) 6.54 \pm \\
0.21(9.05)\end{array}$ & $\begin{array}{c}(6.5) 10.81 \pm \\
0.4(14.22)\end{array}$ & $\begin{array}{c}(5.85) 10.83 \pm \\
0.31(16.84)\end{array}$ & $\begin{array}{c}(6.94) 7.65 \pm \\
0.7(8.35)\end{array}$ & $\begin{array}{l}(4.61) 8.1 \pm \\
0.13(15.45)\end{array}$ & $\begin{array}{c}(8.36) 10.41 \pm \\
0.45(11.17)\end{array}$ & $\begin{array}{l}(8.71) 10.89 \\
\pm 0.64 \\
(14.04)\end{array}$ & $\begin{array}{c}(5.89) 7.97 \pm \\
0.65(14.87)\end{array}$ \\
\hline 11 & h.g & $\begin{array}{c}(0.38) 0.62 \pm \\
0.02(0.84)\end{array}$ & 0.59 & $\begin{array}{c}(0.26) 0.38 \pm \\
0.01(0.49)\end{array}$ & $\begin{array}{c}(0.35) 0.48 \pm \\
0.02(0.63)\end{array}$ & $\begin{array}{c}(0.32) 0.46 \pm \\
0.01(0.64)\end{array}$ & $\begin{array}{l}0.38) 0.4 \pm \\
0.03(0.43)\end{array}$ & $\begin{array}{l}(0.24) 0.37 \\
\pm 0(0.55)\end{array}$ & $\begin{array}{c}(0.47) 0.51 \pm \\
0.01(0.55)\end{array}$ & $\begin{array}{c}(0.44) 0.56 \pm \\
0.03(0.65)\end{array}$ & $\begin{array}{l}(0.3) 0.39 \pm \\
0.02(0.56)\end{array}$ \\
\hline 12 & j2 & $\begin{array}{c}(12.41) 18.42 \pm \\
0.66(25.59)\end{array}$ & 19.11 & $\begin{array}{c}(0.95) 5.27 \pm \\
0.44(11.28)\end{array}$ & $\begin{array}{c}(11.3) 18.34 \pm \\
0.78(27.72)\end{array}$ & $\begin{array}{c}(9.32) 18.83 \pm \\
0.63(32.62)\end{array}$ & $\begin{array}{c}(3.93) 6.33 \pm \\
2.4(8.72)\end{array}$ & $\begin{array}{c}(2.24) 8.54 \\
\pm 0.25 \\
(22.31)\end{array}$ & $\begin{array}{l}(16.26) 19.46 \\
\pm 1.14(22.82)\end{array}$ & $\begin{array}{c}(13.44) 18.38 \\
\pm 1.54 \\
(26.23) \\
\end{array}$ & $\begin{array}{c}(0.71) 7.93 \pm \\
1.15(17.43)\end{array}$ \\
\hline 13 & k2 & $\begin{array}{c}(7.39) 11.43 \pm \\
0.52(17.61)\end{array}$ & 8.31 & $\begin{array}{c}(8.95) 16.16 \pm \\
0.69(24.88)\end{array}$ & $\begin{array}{l}(3.99) 8.47 \pm \\
0.65(20.02)\end{array}$ & $\begin{array}{c}(6.25) 9.71 \pm \\
0.3(15.32)\end{array}$ & $\begin{array}{c}(17.13) 17.76 \\
\pm 0.63 \\
(18.38)\end{array}$ & $\begin{array}{c}(6.82) 18.1 \\
\pm 0.33 \\
(32.45)\end{array}$ & $\begin{array}{c}(4.01) 6 \pm \\
0.56(8.07)\end{array}$ & $\begin{array}{c}(7.03) 10.61 \\
\pm 0.78 \\
(13.12)\end{array}$ & $\begin{array}{l}(10.55) 18.22 \\
\pm 1.38(26.64)\end{array}$ \\
\hline 14 & j2.k2 & $\begin{array}{c}(0.76) 1.81 \pm \\
0.12(2.86)\end{array}$ & 2.39 & $\begin{array}{c}(0.05) 0.39 \pm \\
0.05(1.24)\end{array}$ & $\begin{array}{c}(0.8) 2.63 \pm \\
0.2(5.4)\end{array}$ & $\begin{array}{c}(1.02) 2.17 \pm \\
0.1(3.95)\end{array}$ & $\begin{array}{c}(0.23) 0.36 \pm \\
0.13(0.5)\end{array}$ & $\begin{array}{c}(0.04) 0.55 \\
\pm 0.03 \\
(3.23)\end{array}$ & $\begin{array}{c}(2.29) 3.5 \pm \\
0.31(4.3)\end{array}$ & $\begin{array}{c}(1.26) 1.82 \pm \\
0.12(2.2)\end{array}$ & $\begin{array}{c}(0.03) 0.53 \pm \\
0.09(1.03)\end{array}$ \\
\hline 15 & i1 & (6) 10 (14) & 12 & (0) 0 (4) & (4) 10 (19) & (5) 10 (18) & (2) 3 (4) & (1) $3(9)$ & (9) 13 (16) & (6) 10 (13) & (1) 3 (7) \\
\hline 16 & i2 & (0) $1(3)$ & 2 & (0) $0(2)$ & (2) 4 (8) & $(0) 4(6)$ & (0) 0 (1) & (0) 1 (4) & (3) $4(5)$ & (1) $2(3)$ & (0) $1(2)$ \\
\hline 17 & $\mathbf{i}$ & (7) $12(15)$ & 14 & (0) $2(6)$ & (7) $14(25)$ & (7) $13(22)$ & (2) $3(5)$ & (0) $4(11)$ & (12) $16(20)$ & (9) $12(15)$ & (0) 4 (8) \\
\hline 18 & 1 & $\begin{array}{c}(5.54) 9.89 \pm \\
0.38(13.55)\end{array}$ & 8.74 & $\begin{array}{c}(5.28) 11.88 \pm \\
0.58(20.76)\end{array}$ & $\begin{array}{c}(7.62) 17.77 \pm \\
1.2(31.47)\end{array}$ & $\begin{array}{l}(10.18) 17.89 \\
\pm 0.52(28.1)\end{array}$ & $\begin{array}{l}(18.1) 18.61 \\
\pm 0.5(19.11)\end{array}$ & $\begin{array}{c}(6.29) 16.15 \\
\pm 0.34 \\
(29.63) \\
\end{array}$ & $\begin{array}{l}(9.93) 13.8 \pm \\
0.86(15.99)\end{array}$ & $\begin{array}{c}(6.62) 11.03 \\
\pm 1.04 \\
(16.41) \\
\end{array}$ & $\begin{array}{c}(7.74) 14.7 \pm \\
1.43(26.18)\end{array}$ \\
\hline 19 & lob & (1) $1(2)$ & 1 & (1) $2(3)$ & (2) $3(4)$ & (2) $3(4)$ & (1) $2(3)$ & (1) $2(3)$ & (1) $2(3)$ & (1) $2(3)$ & (1) $2(3)$ \\
\hline 20 & ang & $\begin{array}{c}(25.09) 35.23 \pm \\
1.02(47.55)\end{array}$ & 37.25 & $\begin{array}{c}(21.84) 40.6 \pm \\
1.27(56.4)\end{array}$ & $\begin{array}{c}(40.81) 50.64 \\
\pm 0.89(62.71)\end{array}$ & $\begin{array}{c}(32.22) 48.02 \\
\pm 0.69(61.49)\end{array}$ & $\begin{array}{l}\text { (44) } 50.66 \pm \\
6.66(57.32)\end{array}$ & $\begin{array}{c}(21.05) \\
40.83 \pm 0.54 \\
(57.61) \\
\end{array}$ & $\begin{array}{c}(38.3) 48.68 \pm \\
3.16(62.17)\end{array}$ & $\begin{array}{c}(35.15) 42.05 \\
\pm 2.22 \\
(54.02) \\
\end{array}$ & $\begin{array}{l}(25.64) 38.86 \\
\pm 2.33(51.09)\end{array}$ \\
\hline \multicolumn{12}{|c|}{ Stipules of flowering shoots } \\
\hline 1 & stl & $\begin{array}{c}(3.12) 5.55 \pm \\
0.27(10.51)\end{array}$ & 6.32 & $\begin{array}{c}(1.61) 6.07 \pm \\
0.39(10.73)\end{array}$ & $\begin{array}{l}(4.48) 7.7 \pm \\
0.41(13.16)\end{array}$ & $\begin{array}{c}(4.42) 8.56 \pm \\
0.25(12.64)\end{array}$ & $\begin{array}{l}(5.15) 5.4 \pm \\
0.25(5.64)\end{array}$ & $\begin{array}{c}(3.25) 7.84 \\
\pm 0.17 \\
(16.8) \\
\end{array}$ & $\begin{array}{l}(5.2) 5.84 \pm \\
0.33(7.44)\end{array}$ & $\begin{array}{c}(5.21) 6.65 \pm \\
0.69(10.83)\end{array}$ & $\begin{array}{c}(3.8) 7.03 \pm \\
0.55(11)\end{array}$ \\
\hline 2 & stw & $\begin{array}{c}(0.84) 2.21 \pm \\
0.19(4.78)\end{array}$ & 1.67 & $\begin{array}{c}(0.44) 1.64 \pm \\
0.14(3.72)\end{array}$ & $\begin{array}{c}(0.66) 2.84 \pm \\
0.17(4.23)\end{array}$ & $\begin{array}{c}(1.07) 2.95 \pm \\
0.14(7.32)\end{array}$ & $\begin{array}{c}(1.32) 1.89 \pm \\
0.57(2.46)\end{array}$ & $\begin{array}{l}(0.83) 2.36 \\
\pm 0.08(6.4)\end{array}$ & $\begin{array}{c}(1.52) 2.09 \pm \\
0.19(2.7)\end{array}$ & $\begin{array}{c}(1.58) 2.64 \pm \\
0.39(4.69)\end{array}$ & $\begin{array}{c}(0.73) 2.43 \pm \\
0.32(4.73)\end{array}$ \\
\hline 3 & stt1 & $\begin{array}{c}(8.33) 12.6 \pm \\
0.47(17.67)\end{array}$ & 21 & $\begin{array}{c}(0) \\
0.12 \pm 0.04 \\
(0.67)\end{array}$ & $\begin{array}{c}\text { (6) } 9.64 \pm \\
0.44(17)\end{array}$ & $\begin{array}{c}\text { (5) } 9.64 \pm 0.31 \\
(15.33)\end{array}$ & $\begin{array}{l}(1.67) 4 \pm \\
2.33(6.33)\end{array}$ & $\begin{array}{c}(0) 3.29 \pm \\
0.15(13.33)\end{array}$ & $\begin{array}{c}\text { (9) } 11.94 \pm \\
1.05(15.33)\end{array}$ & $\begin{array}{c}\text { (8) } 9.75 \pm \\
0.53(11.67)\end{array}$ & $\begin{array}{c}(0.67) 3 \pm \\
0.65(8.33)\end{array}$ \\
\hline 4 & stt2 & $\begin{array}{c}(6.33) 8.32 \pm \\
0.28(12)\end{array}$ & 14 & $\begin{array}{c}\text { (0) } 0.14 \pm 0.05 \\
\text { (1) }\end{array}$ & $\begin{array}{c}(3.67) 7.14 \pm \\
0.31(11)\end{array}$ & $\begin{array}{c}\text { (2) } 7.32 \pm 0.29 \\
(11.5)\end{array}$ & $\begin{array}{l}\text { (3) } 3.33 \pm \\
0.33(3.67)\end{array}$ & $\begin{array}{c}\text { (0) } 2.08 \pm \\
0.11(6.67)\end{array}$ & $\begin{array}{c}(5.67) 7.78 \pm \\
0.67(10.33)\end{array}$ & $\begin{array}{c}\text { (5) } 6.88 \pm 0.6 \\
\text { (9) }\end{array}$ & $\begin{array}{c}\text { (0) } 1.6 \pm 0.41 \\
\text { (5) }\end{array}$ \\
\hline 5 & stt & $\begin{array}{c}(14.67) 20.92 \pm \\
0.65(28.67)\end{array}$ & 35 & $\begin{array}{c}\text { (0) } 0.26 \pm 0.07 \\
(1.33)\end{array}$ & $\begin{array}{l}(10.67) 16.78 \\
\pm 0.71(27.33)\end{array}$ & $\begin{array}{c}\text { (7) } 16.96 \pm \\
0.56(25.33)\end{array}$ & $\begin{array}{c}(4.67) 7.33 \pm \\
2.67(10)\end{array}$ & $\begin{array}{c}(0) 5.36 \pm \\
0.23(18.33)\end{array}$ & $\begin{array}{l}(14.67) 19.72 \\
\pm 1.39(22.67)\end{array}$ & $\begin{array}{l}(13) 16.62 \pm \\
1.09(20.33)\end{array}$ & $\begin{array}{c}(0.67) 4.6 \pm 1 \\
(12.33)\end{array}$ \\
\hline
\end{tabular}


Ripe fruits

\begin{tabular}{|c|c|c|c|c|c|c|c|c|c|c|c|}
\hline 1 & frl & $\begin{array}{l}(5.9) 9.23 \pm \\
0.21(11.3)\end{array}$ & 11.07 & $\begin{array}{l}(6.83) 8.9 \pm \\
0.18(11.2)\end{array}$ & $\begin{array}{l}(10.39) 11.93 \\
\pm 0.22(14.4)\end{array}$ & $\begin{array}{c}(9.12) 11.78 \pm \\
0.13(14.43)\end{array}$ & $\begin{array}{c}(12.48) 13.52 \\
\pm 1.04 \\
(14.56)\end{array}$ & $\begin{array}{l}(7.77) 10.15 \\
\pm 0.1(14.6)\end{array}$ & $\begin{array}{c}(10.75) 12.2 \pm \\
0.54(14.27)\end{array}$ & $\begin{array}{l}(8.69) 10.32 \\
\pm 0.4(11.91)\end{array}$ & $\begin{array}{l}(8.06) 9.87 \pm \\
0.31(12.02)\end{array}$ \\
\hline 2 & frw & $\begin{array}{c}(5.4) 8.6 \pm 0.17 \\
(10.55)\end{array}$ & 10.66 & $\begin{array}{c}(5.57) 8.07 \pm \\
0.22(10.1)\end{array}$ & $\begin{array}{c}(7.03) 9.07 \pm \\
0.25(11.23)\end{array}$ & $\begin{array}{c}(7.48) 9.09 \pm \\
0.12(10.96)\end{array}$ & $\begin{array}{l}(8.3) 10.73 \pm \\
2.42(13.15)\end{array}$ & $\begin{array}{c}(5.55) 8.64 \\
\pm 0.1 \\
(12.64) \\
\end{array}$ & $\begin{array}{l}(10.32) 11.32 \\
\pm 0.47(13.28)\end{array}$ & $\begin{array}{c}(6.49) 8.61 \pm \\
0.54(10.82)\end{array}$ & $\begin{array}{l}(7.03) 9.18 \pm \\
0.38(12.29)\end{array}$ \\
\hline 3 & frl.frw & $\begin{array}{c}(0.91) 1.08 \pm \\
0.02(1.29)\end{array}$ & 1.04 & $\begin{array}{c}(0.89) 1.12 \pm \\
0.03(1.53)\end{array}$ & $\begin{array}{c}(1.11) 1.34 \pm \\
0.03(1.74)\end{array}$ & $\begin{array}{l}(1.11) 1.3 \pm \\
0.01(1.57)\end{array}$ & $\begin{array}{c}(1.11) 1.31 \pm \\
0.2(1.51)\end{array}$ & $\begin{array}{c}(0.72) 1.18 \\
\pm 0.01 \\
(1.63)\end{array}$ & $\begin{array}{c}0.99) 1.09 \pm \\
0.02(1.14)\end{array}$ & $\begin{array}{c}(0.96) 1.38 \pm \\
0.21(2.78)\end{array}$ & $\begin{array}{c}(0.86) 1.09 \pm \\
0.03(1.37)\end{array}$ \\
\hline 4 & spl & $\begin{array}{c}(1.28) 1.76 \pm \\
0.04(2.26)\end{array}$ & 1.66 & $\begin{array}{c}(0.97) 1.75 \pm \\
0.09(3.84) \\
\end{array}$ & $\begin{array}{c}(1.6) 2.6 \pm 0.1 \\
(3.71)\end{array}$ & $\begin{array}{c}(1.74) 2.64 \pm \\
0.07(3.99)\end{array}$ & $\begin{array}{c}(1.81) 1.86 \pm \\
0.04(1.9)\end{array}$ & $\begin{array}{c}(1.15) 2 \pm \\
0.03(3.46)\end{array}$ & $\begin{array}{c}(1.84) 2.49 \pm \\
0.21(3.17)\end{array}$ & $\begin{array}{c}(1.33) 1.86 \pm \\
0.22(3.3)\end{array}$ & $\begin{array}{l}(1.25) 1.8 \pm \\
0.09(2.32)\end{array}$ \\
\hline 5 & spw & $\begin{array}{c}(1.04) 1.59 \pm \\
0.04(1.95)\end{array}$ & 1.34 & $\begin{array}{c}(1.12) 1.55 \pm \\
0.04(2)\end{array}$ & $\begin{array}{c}(0.69) 1.13 \pm \\
0.06(2.04)\end{array}$ & $\begin{array}{c}(0.82) 1.41 \pm \\
0.04(2.29)\end{array}$ & $\begin{array}{c}(0.97) 1.04 \pm \\
0.07(1.11)\end{array}$ & $\begin{array}{c}(0.96) 1.59 \\
\pm 0.02 \\
(2.32) \\
\end{array}$ & $\begin{array}{c}(1.18) 1.37 \pm \\
0.06(1.61)\end{array}$ & $\begin{array}{c}(1.18) 1.49 \pm \\
0.07(1.72)\end{array}$ & $\begin{array}{c}(1.22) 1.64 \pm \\
0.08(2.17)\end{array}$ \\
\hline 6 & spl.spw & $\begin{array}{c}(0.78) 1.13 \pm \\
0.04(1.56)\end{array}$ & 1.26 & $\begin{array}{c}(0.79) 1.15 \pm \\
0.06(2.82)\end{array}$ & $\begin{array}{c}(1.64) 2.44 \pm \\
0.11(4.17)\end{array}$ & $\begin{array}{c}(1.05) 1.99 \pm \\
0.07(4.31)\end{array}$ & $\begin{array}{c}(1.65) 1.83 \pm \\
0.18(2.01)\end{array}$ & $\begin{array}{c}(0.77) 1.3 \pm \\
0.03(2.85)\end{array}$ & $\begin{array}{l}(1.53) 1.9 \pm \\
0.16(2.61)\end{array}$ & $\begin{array}{l}\text { (1) } 1.28 \pm \\
0.17(2.45)\end{array}$ & $\begin{array}{c}(0.7) 1.14 \pm \\
0.08(1.7)\end{array}$ \\
\hline 7 & sty & 2 & 2 & 1 & 1 & 1 & 1 & 1 & $1-2$ & $1-2$ & $1-2$ \\
\hline 8 & spp & reflect & erect & reflect & erect & reflect & erect & reflect & erect & reflect & reflect \\
\hline 9 & spsh & obtuse & $\begin{array}{l}\text { acute- } \\
\text { obtuse }\end{array}$ & obtuse & acute & acute & acute-obtuse & acute-obtuse & acute-obtuse & acute-obtuse & obtuse \\
\hline
\end{tabular}




\section{Discussion}

In this study, we give information regarding the occurrence, frequency and habitat preference of ten Crataegus taxa, including hybrids, in three distinct geographical regions in northwestern Romania: western part of the Zărandului Mts, central part of the Transylvanian Plain, and the Călata region (Table 2). We also provide the raw data of morphological measurements and estimates on 34 characters (Table 3 ) to serve for future investigations dedicated to the identification and description of Crataegus taxa, in the same way as it has been provided in previous studies [4, $5,10]$.

Furthermore, our results have provided evidence that the most suitable characters for differentiating between the Crataegus taxa observed in our study area are the number of styles (or pyrenes), fruit length, ratio between sepal length and width, stipule serration, lower sinus depth and serration of the lower leaf lobe. These results are in accordance with the findings of Christensen [4], Christensen [5], Christensen [6,7], and Depypere et al. [10]. Thus, identification keys proposed in our study focus on these characters best suited for differentiating between hybrids and their parental species. The two most widely used books for the identification of vascular plants in Romania [8, 28] differentiate only between Crataegus species and some varieties, while identification keys do not include nothospecies or nothovarieties. In addition, keys prioritize some characters less relevant in taxa differentiation, which can also be highly variable through phenological stages, whereas other more important characters supported by our study and other foreign studies $[4,5,6,7,10]$ are neglected, e.g. inflorescence hairiness, flower diameter and leaf length are important characters to investigate, but are less relevant in differentiating between $C$. monogyna and C. rhipidophylla than fruit length or serration, and morphology of the basal leaf lobe. In addition, neither Ciocârlan [8] nor Sârbu et al. [28] mentioned that exact taxa identification is only possible on generative shoots, while leaf characters included in identification keys are only valid for subterminal leaves of generative shoots.

The results of the multivariate analysis of morphological data revealed that although species and varieties differentiate clearly, hybrids not surprisingly overlap with one or the other parental species (Figure 2). This can be explained by introgression, when repeated rehybridization with one parental species blurs the morphological boundaries between taxa. This way, hybrids become more similar to one of the parental species and will differentiate only in a few characters $[4,5,6,7,10]$. Based on our results, the majority of $C . \times$ kyrtostyla specimens are morphologically more similar to $C$. monogyna than to $C$. rhipidophylla, suggesting that introgression directs this hybrid towards $C$. monogyna. The same or even a more extreme similarity to $C$. monogyna can be observed in the case of $C$. $\times$ media specimens. Habitat fragmentation, the dominance of open habitats and inappropriate forest management may explain why introgression shifts towards $C$. monogyna. In the case of C. $\times$ macrocarpa, specimens are more similar to C. rhipidoplylla that to C. laevigata, suggesting introgression shifts towards $C$. rhipidoplylla. C. laevigata occurs predominantly in older, less fragmented forest habitats, while $C$. rhipidophylla grows usually closer to forest edges and it is more generalist in its habitat requirements, sometimes appearing in grassland habitats as well. Considering these observations, the rehybridization of C. $\times$ macrocarpa with $C$. rhipidophylla is more probable. Similar interpretations connecting morphological variability of taxa and introgression were suggested by Byatt [3], Gosler [14], Christensen [4,5], 
Christensen [6], and Depypere et al. [10].

Acknowledgements: We are very grateful to Edina Gál for her help in sample collection and Orsolya Györfi for her contribution to the morphometric measurements.

\section{REFERENCES}

1. Byatt, J.I., 1975a, Hybridization between Crataegus monogyna Jacq. And C. laevigata (Poiret) DC. in southeastern England, Watsonia, 10: 253-264.

2. Byatt, J.I., 1975b, A critical reappraisal of the status of Crataegus palmstruchii Lindman (Rosaceae), Botanical Journal of Linnean Society, 71: 127-139.

3. Byatt, J.I., 1976, The structure of some Crataegus populations in north-eastern France and south-eastern Belgium, Watsonia, 11: 105-115.

4. Christensen, K. I., 1982, A biometric study of some hybridizing Crataegus populations in Denmark, Nordic Journal of Botany, 2: 537-548.

5. Christensen, K.I., 1984, The morphological variation of some Crataegus populations (Rosaceae) in Greece and Yugoslavia, Nordic Journal of Botany, 4: 585-595.

6. Christensen, K.I., 1992a, The structure of some Crataegus (Rosaceae) populations in Greece, Willdenowia, 22: 65-79.

7. Christensen, K.I., 1992b, Revision of Crataegus sect. Crataegus and nothosect. Crataeguineae (Rosaceae Maloideae) in the Old World, Systematic Botany Monograph, 35: 1-199.

8. Ciocârlan, V., 2000, Flora ilustrată a României, Editura Ceres, București.

9. Cserey, A., 1906, Növényhatározó, Joereges Á. Özv. és Fia Kiadó. Selmeczbánya.

10. Depypere, L., Vander Mijnsbrugge, K., De Cock, K., Verschelde, P., Quataert, P., Van Slycken, J., Goetghebeur, P., 2006, Indigenous species of Crataegus (Rosaceae-Maloideae) in Flanders (Belgium). An explorative morphometric study, Belgian Journal of Botany, 139 (2): 139-152.

11. Dihoru, A., Dihoru, G., 1981, Crataegus monogyna și C. curvisepala, Studii și Cercetări de Biologie, Ser. Biol. Veget., 1: 9-13.

12. Euro+Med 2006-2020, Euro+Med PlantBase - the information resource for Euro -Mediterranean plant diversity, Published on the Internet http://ww2.bgbm.org/EuroPlusMed/ [2020].

13. Fuss, M., 1866, Flora Transsilvaniae Excursoria, Societas Naturae Curiosum Transsilvanica, Cibinii.

14. Gosler, A.G., 1990, Introgressive hybridization between Crataegus monogyna Jacq. and C. laevigata (Poiret) DC. in the Upper Thames Valley, England, Watsonia, 18: 49-62.

15. Janka, V., 1870, Correspondence, Österreichische Botanische Zeitschrift, 20: 316

16. Jávorka, S., 1937, A Magyar Flóra Kis Határozója, Studium, Kecskemét.

17. Kanitz, A., 1879-1881, Plantas Romaniae Hucusque Cognitas, Apud E. Demjén R. Universitas Bibliopolam, Claudiopoli.

18. Kassambara, A. Mundt, F., 2019, factoextra: Extract and Visualize the Results of Multivariate Data Analyses, R package version 1.0.6. https://CRAN.R-project.org/package=factoextra

19. Kerényi-Nagy, V., 2015, A monograph of hawthorns of Carpat-Pannon and Illyr regions, Szent István Egyetem, Mezőgazdasági és Környezet-Tudományi Kar, Gödöllő.

20. Kerényi-Nagy, V., Karácsonyi, C., Negrean, G., Szatmári, P.M., 2016, Rose and Hawthorn data for flora of Sălaj (Szilágy) County (North-West Romania), Studia Universitatis "Vasile Goldiş", Seria Ştiinţele Vieţii, 26 (3): 347- 352.

21. Le, S., Josse, J., Husson, F., 2008, FactoMineR: An R Package for Multivariate Analysis, Journal of Statistical Software, 25 (1), 1-18. 10.18637/jss.v025.i01

22. Liaw, A., Wiener, M., 2002, Classification and Regression by randomForest, $R$ News 2 (3): 18-22.

23. Nyárádi, E.Gy., 1941, Kolozsvár és környékének Flórája, Szöcs Lajos Könyvnyomdája, Kolozsvár.

24. Oklejewicz, K., Chwastek, E.,Szewczyk, M., Bobiec, A., Mitka, J., 2013, Distribution of Crataegus (Rosaceae) in S-E Poland along a gradient of anthropogenic influence, Polish Journal of Ecology, 61 (4): 683-691. 
25. Oprea, A., 2005, Lista critică a plantelor vasculare din România, Editura Universității “Alexandru Ioan Cuza", Iași.

26. Palmer, E.J., 1932, The Crataegus problem, Journal of Arnold Arboretum, 13: 342-362.

27. Sanda, V., Ölleler, K., Burescu, P., 2008, Fitocenozele din România. Sintaxonomie, structură, dinamică și evoluție, Editura Ars Docendi, București.

28. Sârbu, I., Ștefan, N., Oprea, A., 2013, Plante Vasculare din România - Determinator ilustrat, Editura Victor B. Victor, București.

29. Săvulescu, T., Nyárády, E.I. (Eds.), 1956, Flora Republicii Populare Române, Vol. 4. Editura Academiei Republicii Populare Române, București.

30. Sołtys -Lelek, A., Barabasz-Krasny, B., Turis, P., Turisová, I., 2013, The genus Crataegus L. in the western part of the buffer zone of the low Tatras National Park (Slovakia), in accordance with recent morphological and systematic recognition, Modern Phytomorphology, 3: 19-24.

31. Sołtys-Lelek, A., Oliiar, H., 2016, The species of the genus Crataegus L. in the National Nature Park 'Podilskyi Tovtry' (Podolian Hills, Western Ukraine), Biodiversity: Research and Conservation, 44: 25-34.

32. Tutin, T.G., Heywood, V.H., Burges, N.A., Moore, D.M., Valentine, D.H., Walters, S.M., Webb, D.A., (Eds.), 1968, Flora Europaea, Vol. 2: Rosaceae to Umbelliferae, Cambridge University Press, Cambridge.

\section{SPECII ȘI HIBRIZI DE PĂDUCEL (CRATAEGUS L.) ÎN PARTEA DE NORD-VEST A ROMÂNIEI: O RECOMANDARE PENTRU CHEI DE DETERMINARE PE BAZA UNUI STUDIU MORFOMETRIC}

\section{(Rezumat)}

Membrii genului Crataegus L. sunt arbuști sau arbori comuni, cu o răspândire largă în Europa, având o importanță ecologică și agriculturală deosebită. Numărul exact al taxonilor este totuși controversat, datorită hibridizării frecvente între speciile simpatrice, respectiv introgresiei genelor. Considerând numărul redus de lucrări legate de Crataegus în literatura de botanică din România, am studiat distribuția și morfologia acestui gen în partea de Nord-Vest a ţării. Am colectat material de ierbar pentru identificare din trei subunități geografice (Munții Zărandului, Câmpia Transilvaniei, Dealurile Călatei) din diverse habitate, pajiști, habitate forestiere și liziere. Pe acest material, am efectuat un studiu morfometric măsurând în total 34 de caractere diagnostice ale fructelor, frunzelor şi stipelelor tulpinilor generative. Am folosit metodele "PCA" și "Random Forest" pentru a selecta cele mai "bune" (sau puternice) caractere diagnostice ale speciilor și hibrizilor. Am identificat zece taxoni de Crataegus, specii, subspecii, varietăţi și hibrizii acestora (nothospecii): Crataegus monogyna (cu răspândire în pajiști), C. rhipidophylla var. rhipidophylla, C. rhipidophylla var. lindmannii și C. laevigata subsp. laevigata, C. laevigata subsp. palmstruchii (cu răspândire predominant în habitate forestiere), $C . \times$ kyrtostyla nothovar. domicensis, $C . \times$ media, $C . \times$ macrocarpa nothovar. macrocarpa și $C . \times$ macrocarpa nothovar. hadensis (predominant în lizierea habitatelor forestiere). Taxonul cel mai comun și larg răspândit a fost nothotaxonul $C . \times$ kyrtostyla nothovar. kyrtostyla (comună în pajiști dar sporadică în habitatele forestiere). Caracterele cele mai "bune" pentru diferențierea taxonilor au fost numărul stilelor, lungimea fructelor, numărul dentaţiilor pe stipele, poziția sepalelor pe fructe, numărul serațiilor pe lobul bazal al frunzei subterminale, raportul dintre partea serată și partea întreagă în cazul lobului bazal al frunzei, adâncimea sinusului bazal al frunzei și raportul dintre lungimea și lățimea sepalelor. Pe baza analizei morfometrice considerând și descrierile din literatura de specialitate, am elaborat cheile de determinare ale acestui gen, fiind incluși toți taxonii cu prezență certă în România. Adițional, am ilustrat cei șase taxoni cei mai comuni identificați în acest studiu. 